\title{
Molecular analysis of Salmonella enteritidis isolates from the Caribbean by pulsed-field gel electrophoresis
}

\author{
Abiodun Adesiyun, ${ }^{1}$ Andrew Carson, ${ }^{2}$ Kelly McAdoo, ${ }^{2}$ \\ and Craig Bailey ${ }^{2}$
}

\begin{abstract}
Using pulsed-field gel electrophoresis (PFGE), between 1987 and 1996 we analyzed Salmonella enteritidis isolates from gastroenteritis cases in four Caribbean countries: Barbados, Saint Kitts and Nevis, Saint Lucia, and Trinidad and Tobago. We also determined the resistance of the isolates to 12 antimicrobial agents. Of the 129 isolates of S. enteritidis available for testing, DNA digested by XbaI revealed 13 distinctive PFGE patterns. The most prevalent XbaI PFGE patterns were group 1 (88 of 129 isolates, 68.2\%) and group 2 (26 of 129, 20.2\%). The patterns found among $\mathrm{S}$. enteritidis isolates correlated with the geographical origin of the isolates. Of the 28 isolates from Barbados, 20 of them (71.4\%) belonged to XbaI PFGE group 2 , and of the 93 isolates from Trinidad and Tobago, 78 of them (83.9\%) belonged to group 1 . SpeI digestion of S. enteritidis genome was not as discriminatory as XbaI.

Overall, of the 129 isolates, 67 of them (51.9\%) exhibited resistance to one or more of the 12 antimicrobial agents that we tested. The prevalence of resistance was $53.8 \%$ for the S. enteritidis isolates tested from Trinidad and Tobago, 50.0\% for those from Barbados, $28.6 \%$ for those from Saint Lucia, and 100.0\% for one isolate from the island of Saint Kitts. Resistance was highest to triple sulfur (59 of 129 isolates, 45.7\%), followed by furadantoin (10 of 129, $7.8 \%$ ), ampicillin (7 of 129,5.4\%), and carbamycin (5 of 129, 3.9\%).
\end{abstract}

Salmonella enteritidis has become an important cause of food poisoning throughout the world (1-3). For a long time in the Caribbean region $S$. enteritidis was rarely associated with human

\footnotetext{
1 University of the West Indies, Faculty of Medical Sciences, School of Veterinary Medicine, St. Augustine, Trinidad and Tobago. Send correspondence to: Professor A. A. Adesiyun, Faculty of Medical Sciences, School of Veterinary Medicine, The University of the West Indies, St. Augustine, Trinidad and Tobago; telephone: (868)-645-8329; fax: (868) 645-9865; e-mail: abiodunadesiyun@hotmail.com

2 University of Missouri, College of Veterinary Medicine, World Health Organization Collaborating Center for Enteric Zoonoses, Columbia, Missouri, United States of America.
}

infections (4). In the early 1990s, however, a number of outbreaks and sporadic cases implicating the microorganism were reported (5). There was a subsequent phenomenal increase in the involvement of $S$. enteritidis in reported cases of food poisoning (6).

Various methods have been used for salmonella epidemiological testing, including antibiotic testing, serotyping, and phage typing (7-9). Recently, various molecular techniques have been applied to characterize $S$. enteritidis and to conduct epidemiological investigations. Among these techniques are plasmid profile analysis (10), DNA restriction fragment polymorphisms (11), chromosomal probe fingerprinting (12), and pulsed-field gel electrophoresis (PFGE) $(13,14)$.

To date, there have been no reports on the characteristics of $S$. enteritidis isolated from the Caribbean, nor have there been reports on the relatedness of isolates implicated in foodborne gastroenteritis.

This study utilized PFGE to investigate the relationship between $S$. enteritidis isolates recovered from gastroenteritis cases in various Caribbean countries and to determine the antibiograms of the isolates. 


\section{MATERIALS AND METHODS}

\section{Sources of S. enteritidis isolates}

The Caribbean Epidemiology Center (CAREC), Port of Spain, Trinidad, is the regional reference laboratory for Salmonella, and it served as the source of the $S$. enteritidis isolates we studied. All Salmonella clinical isolates from CAREC's 21 Member Countries (mainly English-speaking) in the Caribbean sub-region are sent to CAREC for serological typing. Table 1 shows the number of $S$. enteritidis isolates from gastroenteritis cases (sporadic or outbreak) that we obtained from CAREC and studied. All viable isolates of $S$. enteritidis in the collection of CAREC were selected for study.

Overall, we tested a total of 129 S. enteritidis isolates, with 122 originating from human clinical cases and 7 (from Trinidad and Tobago) from animals. It was not possible to determine which of the isolates originated from outbreaks of gastroenteritis since in the Caribbean region there is no routine investigation or reporting of foodborne outbreaks.

\section{Preparation of bacterial DNA, restriction digests, and running of pulsed-field gel electrophoresis}

For our testing all the S. enteritidis strains were plated for isolation on blood agar. Colonies of pure cultures were then inoculated into $5 \mathrm{~mL}$ of brain heart infusion broth and incubated overnight at $37{ }^{\circ} \mathrm{C}$ to attain log phase growth. An aliquot $(1.3 \mathrm{~mL})$ of cell suspension of each isolate was centrifuged at $12000 \times \mathrm{g}$ for $90 \mathrm{sec}-$ onds. To prepare bacterial DNA we used a procedure described earlier (15).

Agarose plugs were cut into slices to fit gel wells and equilibrated for 15 minutes at room temperature in tubes containing $200 \mu \mathrm{L}$ of restriction enzyme buffer (Stratagene, La Jolla, California, United States of America). The buffer was then decanted and replaced with $200 \mu \mathrm{L}$ of fresh restriction enzyme buffer for a further 15 minutes of equilibration at room temperature. Restriction digests were done as described earlier (15).

A 1.0\% SeaKem gel (FMC BioProducts, Rockland, Maine, United States) was prepared in 0.5X TBE buffer 60-90 min prior to completion of the restriction enzyme digestion of bacterial DNA and allowed to solidify at room temperature. DNA digested with either XbaI or SpeI in gel slices was placed in the wells of SeaKem gel and sealed in place with molten $1 \%$ agarose in 0.5X TBE buffer. To wells 1 and 15 of each gel was added standard molecular size markers (lambda ladder). For each run, the sealing agar was allowed to solidify at room temperature and the gel was thereafter transferred into a CHEF-DR III electrophoresis cham- ber (Bio-Rad Laboratories, Hercules, California, United States) and submerged in chilled 0.5X TBE. Electrophoresis was performed at $200 \mathrm{~V}$ for $20 \mathrm{~h}$ with the pulse time ramped from 2 seconds to 40 seconds and the buffer temperature maintained at $14{ }^{\circ} \mathrm{C}$. The gel was subsequently stained in ethidium bromide $(0.5 \mu \mathrm{g} / \mathrm{mL})$ solution for $30 \mathrm{~min}$ at room temperature and then destained in distilled water for approximately $1 \mathrm{~h}$ prior to photography under ultraviolet light.

\section{Determination of PFGE patterns}

Polaroid photographs of PFGE patterns were recorded by a desktop scanner (Hewlett-Packard, Boise, Idaho, United States) and subsequently subjected to a computerized artificial neural network analysis described earlier (15). Grouping was based on location and number of bands in the range of $50 \mathrm{~kb}$ to $550 \mathrm{~kb}$.

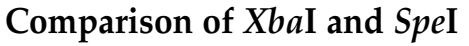 PFGE patterns}

Following the identification of the PFGE distinct groups detected by $\mathrm{Xba \textrm {I }}$ digestion, a representative of each of the 13 groups subjected to $\mathrm{XbaI}$ digestion was digested with SpeI restriction enzyme using fresh plugs, and the pattern was noted.

TABLE 1. Isolates of S. enteritidis submitted and studied, by source country and year of isolation, four Caribbean countries, 1987-1996

\begin{tabular}{|c|c|c|c|c|c|c|c|c|c|c|c|c|c|c|c|}
\hline \multirow[b]{3}{*}{ Year } & \multicolumn{3}{|c|}{ Trinidad and Tobago } & \multicolumn{3}{|c|}{ Barbados } & \multicolumn{3}{|c|}{ Saint Lucia } & \multicolumn{3}{|c|}{ Saint Kitts and Nevis } & \multicolumn{3}{|c|}{ All sources } \\
\hline & \multirow{2}{*}{$\frac{\text { Submitted }}{\text { No. }}$} & \multicolumn{2}{|c|}{ Studied } & \multirow{2}{*}{$\frac{\text { Submitted }}{\text { No. }}$} & \multicolumn{2}{|c|}{ Studied } & \multirow{2}{*}{$\frac{\text { Submitted }}{\text { No. }}$} & \multicolumn{2}{|c|}{ Studied } & \multirow{2}{*}{$\frac{\text { Submitted }}{\text { No. }}$} & \multicolumn{2}{|c|}{ Studied } & \multirow{2}{*}{$\frac{\text { Submitted }}{\text { No. }}$} & \multicolumn{2}{|c|}{ Studied } \\
\hline & & No. & $\%$ & & No. & $\%$ & & No. & $\%$ & & No. & $\%$ & & No. & $\%$ \\
\hline 1987 & 0 & 0 & 0.0 & 2 & 1 & 50.0 & 0 & 0 & 0.0 & 0 & 0 & 0.0 & 2 & 0 & 0.0 \\
\hline 1989 & 0 & 0 & 0.0 & 5 & 1 & 20.0 & 6 & 1 & 16.7 & 0 & 0 & 0.0 & 11 & 2 & 18.2 \\
\hline 1990 & 1 & 0 & 0.0 & 10 & 3 & 30.0 & 3 & 2 & 66.7 & 0 & 0 & 0.0 & 14 & 5 & 35.7 \\
\hline 1991 & 1 & 1 & 100.0 & 20 & 3 & 15.0 & 0 & 0 & 0.0 & 0 & 0 & 0.0 & 21 & 4 & 19.0 \\
\hline 1992 & 1 & 1 & 100.0 & 19 & 5 & 26.3 & 0 & 0 & 0.0 & 0 & 0 & 0.0 & 20 & 6 & 30.0 \\
\hline 1993 & 0 & 0 & 0.0 & 22 & 4 & 18.2 & 2 & 0 & 0.0 & 1 & 1 & 100.0 & 25 & 5 & 20.0 \\
\hline 1994 & 12 & 8 & 66.7 & 18 & 5 & 27.8 & 4 & 2 & 50.0 & 0 & 0 & 0.0 & 34 & 15 & 44.1 \\
\hline 1995 & 50 & 49 & 98.0 & 13 & 5 & 38.5 & 2 & 2 & 100.0 & 0 & 0 & 0.0 & 65 & 56 & 86.2 \\
\hline 1996 & 70 & 34 & 48.6 & 4 & 1 & 25.0 & 0 & 0 & 0.0 & 0 & 0 & 0.0 & 74 & 35 & 47.3 \\
\hline Total & 135 & $93^{a}$ & 68.9 & 113 & 28 & 24.8 & 17 & 7 & 41.2 & 1 & 1 & 100.0 & 266 & 129 & 48.5 \\
\hline
\end{tabular}

a Seven of the 93 isolates from Trinidad and Tobago that were studied came from animal sources; the other 86 were all from human gastroenteritis cases. 


\section{Determination of antibiograms of isolates}

To determine the antibiograms of the $S$. enteritidis isolates we used the agar diffusion method of the National Committee for Clinical Laboratory Standards (16). Twelve antimicrobial agents on disks (Difco Laboratories, Inc., Detroit, Michigan, U.S.A.) were used, and their concentrations were: ampicillin $(30 \mu \mathrm{g})$, carbamycin $(100 \mu \mathrm{g})$, chloramphenicol $(30 \mu \mathrm{g})$, clindamycin $(30 \mu \mathrm{g})$, furadantoin $(300 \mu \mathrm{g})$, gentamycin (10 units), kanamycin (30 $\mu \mathrm{g})$, nalidixic acid $(30 \mu \mathrm{g})$, streptomycin $(10 \mu \mathrm{g})$, sulphamethoxazole/trimethoprim $(25 \mu \mathrm{g})$, triple sulfur $(300 \mu \mathrm{g})$, and tetracycline $(30 \mu \mathrm{g})$. We measured the zone sizes and used the criteria provided by the disc manufacturer to determine the resistance or sensitivity of the isolates.

\section{RESULTS}

Figure 1 shows the fragment patterns of S. enteritidis genome digested with $\mathrm{XbaI}$; there were 13 distinctive cleavage patterns among the 129 isolates of S. enteritidis that we tested.

Digestion with restriction enzyme SpeI of the same DNA preparations used for the XbaI digestion (shown in Figure 1) is displayed in Figure 2. Only eight distinct fragment patterns were detected (wells 2; $4 ; 7 ; 8 ; 3$ and $11 ; 5,6$, 9 , and 10; 12 and 13 ; and 14).

The sources of the $S$. enteritidis isolates from 1987 through 1996 are shown by country in Table 1; isolates for 1988 were unavailable from CAREC for study. Over the first part of this period, from 1987 through 1993, the four countries submitted a total of 93 S. enteritidis isolates: $3(3.2 \%)$ from Trinidad and Tobago, 78 (83.9\%) from Barbados, 11 (11.8\%) from Saint Lucia, and $1(1.2 \%)$ from the island of Saint Kitts.

The pattern was different in the subsequent period, of 1994 through 1996, with Trinidad and Tobago replacing Barbados as the country from which the largest number of $S$. enteritidis isolates were reported. Of a total of 173
FIGURE 1. Pulsed-field gel electrophoresis patterns of $S$. enteritidis isolates generated by enzyme Xbal. Lanes 1 and 15 contained molecular size markers (lambda ladder). Lanes 2-14 show distinct cleavage patterns observed among the $129 \mathrm{~S}$. enteritidis isolates tested

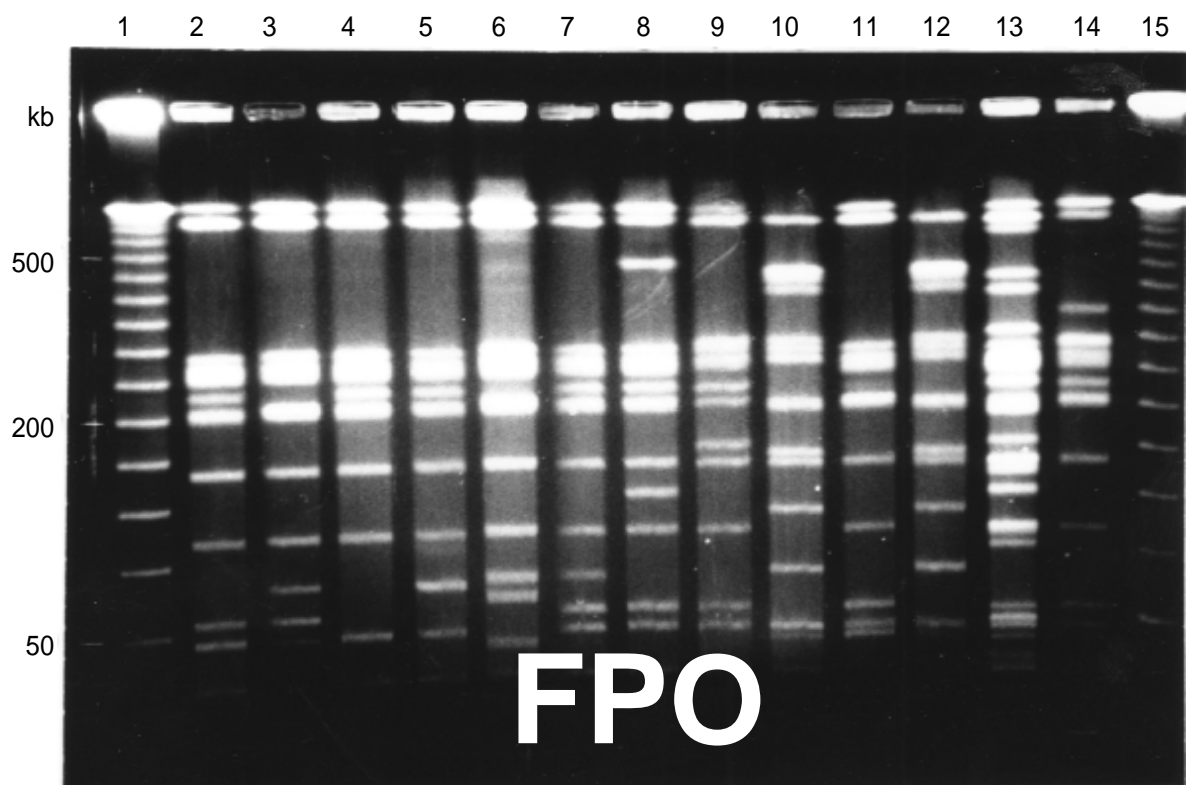

isolates submitted to CAREC over those 3 years, 132 of them $(76.3 \%)$ were from Trinidad and Tobago, 35 (20.2\%) from Barbados, $6(3.5 \%)$ from Saint Lucia, and $0(0.0 \%)$ from Saint Kitts and Nevis.

From 1987 through 1996 we tested a total of 129 isolates of $S$. enteritidis. Of that total, 88 of them $(68.2 \%)$ belonged to XbaI PFGE group 1, and $26(20.2 \%)$ belonged to $\mathrm{XbaI}$ PFGE group 2 (Table 2). Only 4 (3.1\%) belonged to group 3 ,

FIGURE 2. Pulsed-field gel electrophoresis separation of restriction fragments of $S$. enteritidis genome digested with Spel. Lanes 1 and 15 contained lambda ladder molecular size marker. Lanes 2-14 contained genomes representative of the 13 Xbal patterns

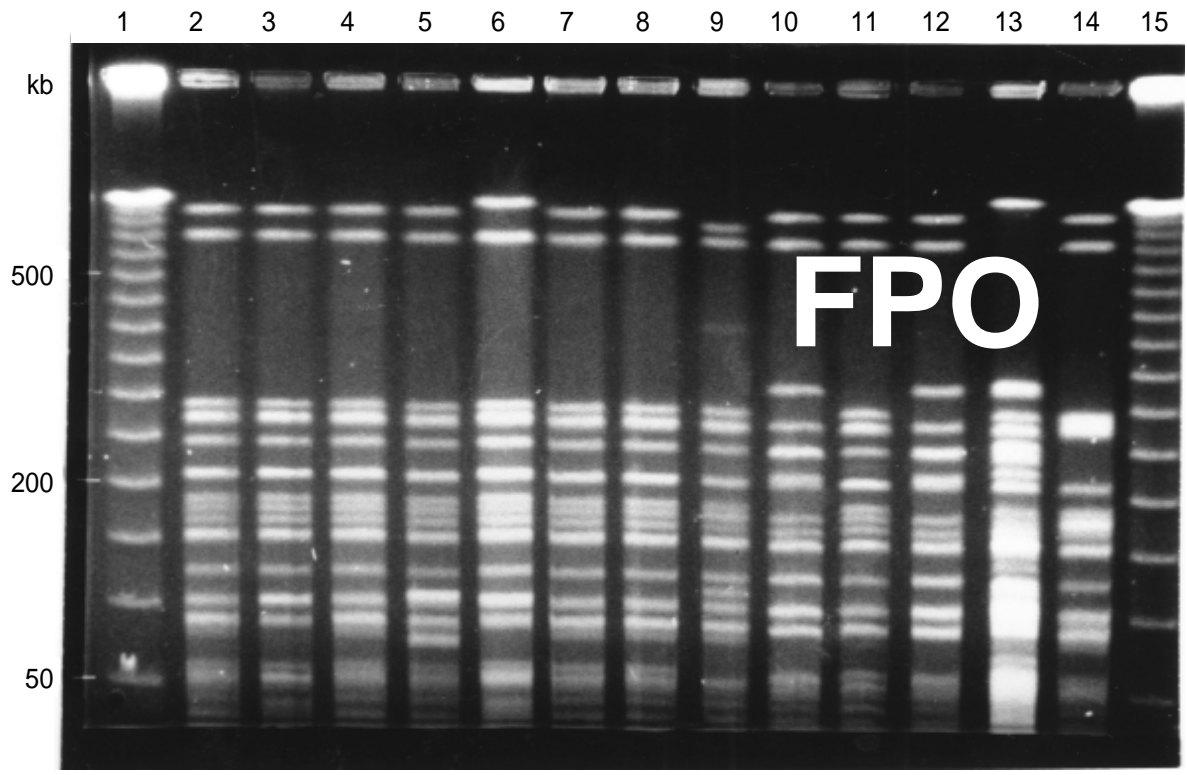


TABLE 2. Xbal pulsed-field gel electrophoresis groups of S. enteritidis isolates, by year, four Caribbean countries, $1987-1996$

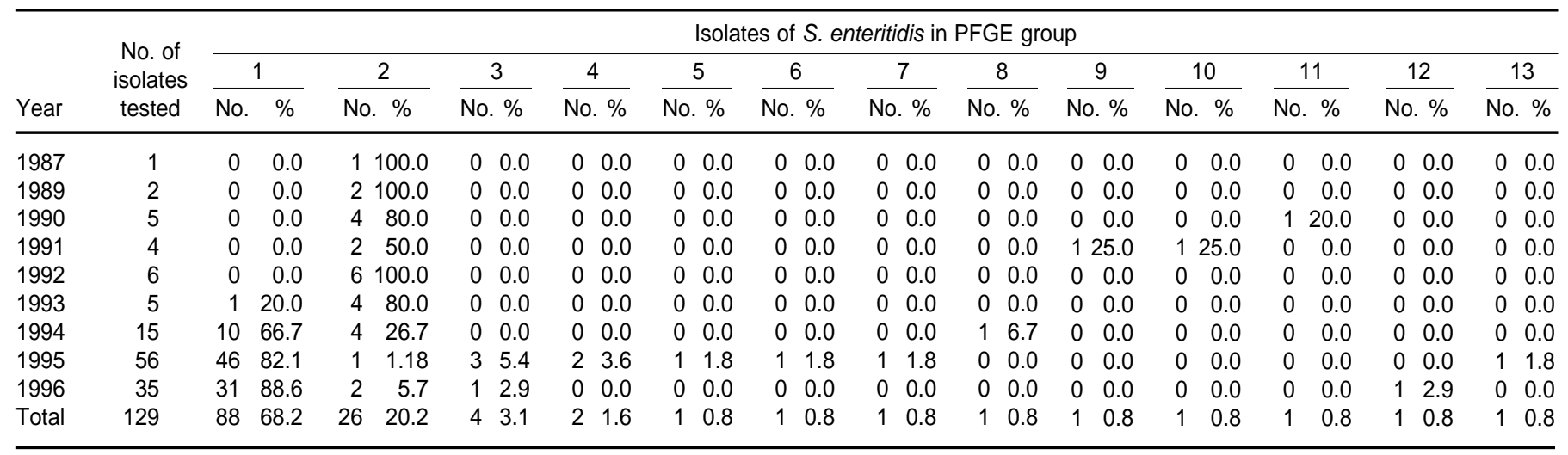

$2(1.6 \%)$ belonged to group 4 , and the other nine groups had 1 isolate each.

In the 1987-1993 period, of the 23 isolates tested, only $1(4.3 \%)$ was classified in group 1, and $19(82.6 \%)$ belonged to group 2. However, for the 1994-1996 period, of a total of 106 isolates tested, 87 of them $(82.1 \%)$ were in group 1 , and only $7(6.6 \%)$ belonged to group 2 .

The distribution of XbaI PFGE groups among the $S$. enteritidis isolates tested from the four countries is shown in Table 3. In Trinidad and Tobago, group 1 was the most prevalent (78 of 93 isolates tested, or $83.9 \%$ ). In Barbados, group 2 was the most common (20 of 28 , or $71.4 \%$ ). Saint Lucian isolates of $S$. enteritidis had the same frequency of occurrence, $42.9 \%$, for both group 1 and group 2 .

In Trinidad and Tobago, regardless of the year and geographical location of source of $S$. enteritidis isolates within the country, PFGE group 1 isolates were the most prevalent. Five $(71.4 \%)$ of the $7 \mathrm{~S}$. enteritidis of animal origin also belonged to PFGE group 1. In 19947 of the $8(87.5 \%)$ isolates that were tested belonged to group 1 , in 199540 of $49(81.6 \%)$ did so, and in 199631 of $34(91.2 \%)$ did so.

Of the 129 isolates of $S$. enteritidis tested, 67 of them (51.9\%) exhibited resistance to one or more antimicrobial agents (Table 4). Overall, resistance was highest to triple sulfur (59 of 129 isolates, or $45.7 \%$ ), a pattern that was true for all four of the countries. The resistance levels for the other antimicrobial agents tested were all noticeably lower, $7.8 \%$ or less. The resistance to the various antimicrobial agents was similar in all four of the countries. All of the isolates tested were sensitive to nalidixic acid, chloramphenicol, and sulphamethoxazole/trimethoprim.
A total of 12 resistant patterns were observed, with resistance to triple sulfur alone most frequent (46 isolates). A total of $59(45.7 \%)$ of the 129 isolates, however, were resistant to either triple sulfur alone or triple sulfur in combination with other antimicrobial agents.

\section{DISCUSSION}

Of the four countries from which we studied $S$. enteritidis strains, only one, Trinidad and Tobago, recorded a significant increase in the absolute number of S. enteritidis isolates from 1994 to 1996. Barbados, on the other hand, had relatively high numbers of $S$. enteritidis from as early as 1990. The situation in Barbados might be explained in part by the country's heavy dependence on tourism. Worldwide, there has been a surge in the involvement of $S$. enteritidis in

TABLE 3. Xbal pulsed-field gel electrophoresis groups of S. enteritidis isolates, by country of origin, four Caribbean countries, $1987-1996$

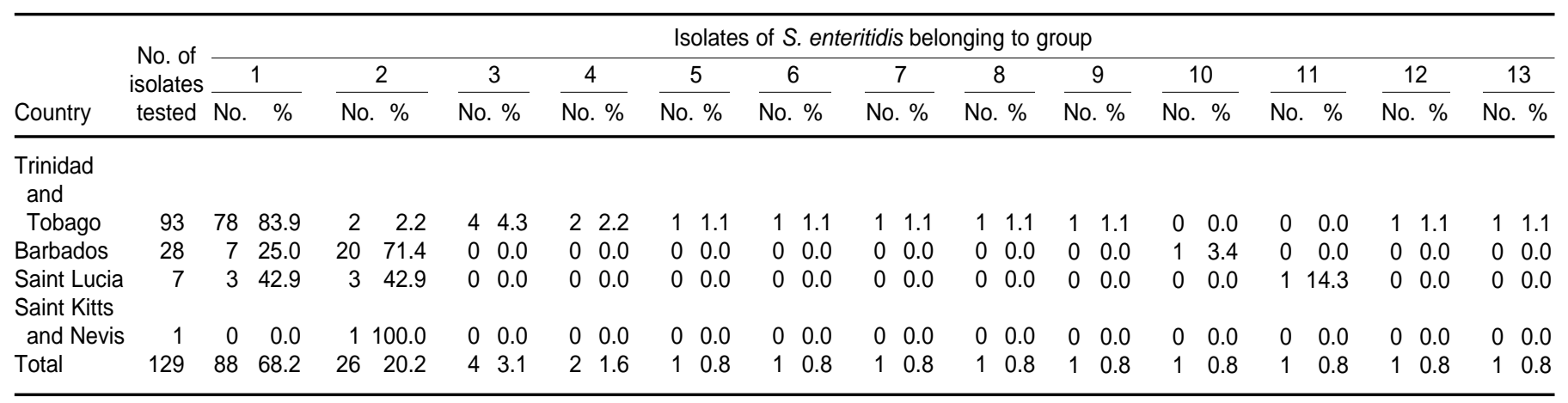


TABLE 4. Antibiograms of S. enteritidis isolates from various sources, using 12 antimicrobial agents, four Caribbean countries, 1987-1996

\begin{tabular}{|c|c|c|c|c|c|c|c|c|c|c|c|c|c|c|c|c|c|c|c|c|}
\hline \multirow[b]{3}{*}{ Country } & \multirow{3}{*}{$\begin{array}{c}\text { No. of } \\
\text { isolates } \\
\text { tested }\end{array}$} & \multirow{2}{*}{\multicolumn{2}{|c|}{$\begin{array}{l}\text { Isolates resistant } \\
\text { to antimicrobials } \\
\text { c,d }\end{array}$}} & \multicolumn{17}{|c|}{ Resistance to specific antimicrobials ${ }^{b}$} \\
\hline & & & & \multicolumn{2}{|c|}{ SSS } & \multicolumn{2}{|c|}{ FD } & \multicolumn{2}{|c|}{ AMP } & \multicolumn{2}{|c|}{ CB } & \multicolumn{2}{|c|}{$\mathrm{S}$} & \multicolumn{2}{|c|}{$\mathrm{CL}$} & \multicolumn{2}{|c|}{ GN } & \multicolumn{2}{|c|}{$\mathrm{K}$} & TE \\
\hline & & No. & $\%$ & No. & $\%$ & No. & $\%$ & No. & $\%$ & No. & $\%$ & No. & $\%$ & No. & & No. & $\%$ & No. & $\%$ & No. \% \\
\hline \multicolumn{21}{|l|}{ Trinidad and } \\
\hline Tobago & 93 & 50 & 53.8 & 45 & 48.4 & 7 & 7.5 & 5 & 5.4 & 2 & 2.2 & 2 & 2.2 & 1 & 1.1 & 2 & 2.2 & 1 & 1.1 & $\begin{array}{ll}1 & 1.1\end{array}$ \\
\hline Barbados & 28 & 14 & 50.0 & 12 & 42.9 & 2 & 7.1 & 1 & 3.6 & 2 & 7.1 & 2 & 7.1 & 0 & 0.0 & 0 & 0.0 & 0 & 0.0 & $\begin{array}{ll}0 & 0.0\end{array}$ \\
\hline Saint Lucia & 7 & 2 & 28.6 & 1 & 14.3 & 1 & 14.3 & 1 & 14.3 & 0 & 0.0 & 0 & 0.0 & 1 & 14.3 & 0 & 0.0 & 0 & 0.0 & $0 \quad 0.0$ \\
\hline \multicolumn{21}{|l|}{ Saint Kitts } \\
\hline and Nevis & 1 & 1 & 100.0 & 1 & 100.0 & 0 & 0.0 & 0 & 0.0 & 0 & 0.0 & 0 & 0.0 & 0 & 0.0 & 0 & 0.0 & 0 & 0.0 & $\begin{array}{ll}0 & 0.0\end{array}$ \\
\hline Total & 129 & 67 & 51.9 & 59 & 45.7 & 10 & 7.8 & 7 & 5.4 & 5 & 3.9 & 4 & 3.1 & 2 & 1.6 & 2 & 1.6 & 1 & 0.8 & $\begin{array}{ll}1 & 0.8\end{array}$ \\
\hline
\end{tabular}

a All 129 isolates of $S$. enteritidis were sensitive to chloramphenicol, nalidixic acid, and sulphamethoxazole/trimethoprim.

b $\mathrm{SSS}=$ triple sulfur; $\mathrm{FD}=$ furadantoin; $\mathrm{AMP}=$ ampicillin; $\mathrm{CB}=$ carbamycin; $\mathrm{S}=$ streptomycin; $\mathrm{CL}=$ clindamycin; $\mathrm{GN}=$ gentamycin; $\mathrm{K}=$ kanamycin; $\mathrm{TE}=$ tetracycline.

c Number of isolates resistant to one or more of the antimicrobial agents.

d A total of 12 resistant patterns were observed, namely, SSS (46 isolates), SSS-FD (7 isolates), AMP (2 isolates), FD (2 isolates), CL-AMP-CB (2 isolates), S-GN-SSS (2 isolates), SSS-AMP ( 1 isolate), K-SSS ( 1 isolate), SSS-TE (1 isolate), AMP-CB (1 isolate), S-FD-CB ( 1 isolate), and S-SSS-AMP-CB ( 1 isolate). Where only one antimicrobial agent is indicated, it means that resistance was exhibited to that agent only.

human gastroenteritis $(2,17,18)$. It is possible that visitors to Barbados brought in the infections from North America or Europe, two of the areas where S. enteritidis has been increasingly involved in human gastroenteritis.

It was of epidemiological significance to find that the strains of S. enteritidis displayed a distinct geographical distribution. The XbaI PFGE group 1 strains were predominantly found in Trinidad and Tobago, while group 2 strains were much more prevalent in Barbados. Although there was a slight overlap of $\mathrm{XbaI}$ PFGE groups 1 and 2 between the two countries, it was evident that the strains of $S$. enteritidis responsible for gastroenteritis in Trinidad and Tobago and in Barbados differ significantly. The small number of isolates of $S$. enteritidis available for study from Saint Lucia and from Saint Kitts and Nevis made it difficult to draw any inferences on the PFGE patterns of isolates from these countries.

In Trinidad and Tobago, regardless of the source of strains (human versus animals, and geographical location) of $S$. enteritidis and the year of isolation, $\mathrm{XbaI}$ PFGE group 1 strains predominated, emphasizing the importance of this strain in gastroenteritis in the country. However, it was difficult to associate the various $\mathrm{XbaI}$ groups with outbreaks of gastroenteritis caused by
S. enteritidis. That is because outbreaks of foodborne disease are rarely reported or investigated in the Caribbean. Therefore, a high percentage of the $S$. enteritidis isolates sent to CAREC for serotyping may have originated from either sporadic cases or outbreaks. PFGE has been employed in various studies for epidemiological investigations in sporadic and large outbreaks of salmonellosis caused by S. enteritidis $(3,14,19)$.

If was of zoonotic relevance that in Trinidad and Tobago some of the strains of $S$. enteritidis of animal origin belonged to the same PFGE group as those isolated from human gastroenteritis. S. enteritidis infections in humans have been reported to originate frequently from animals, particularly poultry (20-22).

Our finding that $\mathrm{XbaI}$ restriction enzyme was superior to SpeI restriction enzyme in discriminating the strains of $S$. enteritidis was hardly a surprise; other researchers have reported similar findings $(14,19)$.

Regardless of the country of origin or the year of isolation of $S$. enteritidis, we found that the prevalence of resistance to most of the antimicrobial agents that we tested was low. Resistance to triple sulfur was comparatively high (46\%), a finding in agreement with other reports $(23,24)$. Resistances to furadantoin $(7.8 \%)$, ampicillin $(5.4 \%)$, and carbamycin
(3.9\%) were also similar to what others have reported (21). Outside the Caribbean, however, a considerably higher prevalence of resistance to ampicillin has been reported. In Greece, for example, $30 \%$ of $S$. enteritidis isolates were resistant (18). While the antibiograms of $S$. enteritidis strains can be used to determine the relatedness of strains (18), they were not helpful in epidemiological association in this study.

From our research we can conclude that $S$. enteritidis has attained some clinical significance in gastroenteritis in the Caribbean, with a particularly dramatic change in Trinidad and Tobago. In addition, the PFGE we performed clearly demonstrated that in Barbados and in Trinidad and Tobago there are distinctly different strains of S. enteritidis involved in gastroenteritis.

Acknowledgments. We thank the Inter-American Development Bank for funding the stay of the principal author at the University of Missouri, and for part-sponsorship of the research materials. The assistance rendered by Denise Clarke of the Caribbean Epidemiology Center in making the isolates available is appreciated. Zobaida Khan of the Public Health Laboratory, Port of Spain, kindly assisted in subculturing the isolates. Beverly Hartman is thanked for typing the manuscript. 


\section{REFERENCES}

1. United States of America, Centers for Disease Control and Prevention. Salmonella surveillance report: annual summary. Atlanta: CDC; 1990.

2. Rodrigue DC, Tauxe RV, Rowe B. International increase in Salmonella enteritidis: a new pandemic? Epidemiol Infect 1990;105:21-27.

3. Suzuki $Y$, Ishihara $M$, Matsumoto $M$, Arakawa S, Saito M, Ishikawa M, et al. Molecular epidemiology of Salmonella enteritidis: an outbreak and sporadic cases studied by means of pulsed-field gel electrophoresis. J Infect 1995; 31:211-217.

4. Hull BP, Spence L, Bassett D, Swanston WH, Tikasingh ES. The relative importance of rotavirus and other pathogens in the etiology of gastroenteritis in Trinidadian children. Am J Trop Med Hyg 1982;31:142-148.

5. Caribbean Epidemiology Centre. Surveillance report, 1990. Port of Spain, Trinidad and Tobago: CAREC; 1990.

6. Caribbean Epidemiology Centre. Surveillance reports, 1990-1996. Port of Spain, Trinidad and Tobago: CAREC; 1996.

7. United States of America, Centers for Disease Control and Prevention. Salmonella surveillance report, 1989. Atlanta: CDC; 1989.

8. Hickman-Brenner FW, Stubbs AD, Farmer JJ $3 \mathrm{~d}$. Phage typing of Salmonella enteritidis in the United States. J Clin Microbiol 1991;29: 2817-2823.

9. Rivera MJ, Rivera N, Castillo J, Rubio MC, Gomez-Lus R. Molecular and epidemiological study of Salmonella clinical isolates. J Clin Microbiol 1991; 29:927-932.

10. Threlfall EJ, Rowe B, Ward LR. Subdivision of Salmonella enteritidis phage types by plasmid profile typing. Epidemiol Infect 1989;102: $459-465$
11. Nastasi A, Mammina C, Villafarte MR. rDNA fingerprinting as a tool in epidemiological analysis of Salmonella typhi infections. Epidemiol Infect 1991;107:565-576.

12. Bohm $\mathrm{H}$, Karch $\mathrm{H}$. DNA fingerprinting of Escherichia coli $0157: 47$ strains by pulsed-field gel electrophoresis. J Clin Microbiol 1992;30: 2169-2172.

13. Powell NG, Threlfall EJ, Chart H, Schofield $\mathrm{SL}$, Rowe B. Correlation of change in phage type with pulsed field profile and $16 \mathrm{~S}$ rrn profile in Salmonella enteritidis phage types 4, 7 and 9a. Epidemiol Infect 1995;114: 403-411.

14. Thong K, Ngeow $Y$, Altwegg M, Navaratnam $P$, Pang T. Molecular analysis of Salmonella enteritidis by pulsed-field gel electrophoresis and ribotyping. J Clin Microbiol 1995;33: 1070-1074.

15. Carson CA, Kelly JM, McAdoo KK, Wang D, Higgins B, Bailey CW, et al. Escherichia coli 0157:H7 restriction pattern recognition by artificial neural network. J Clin Microbiol 1995; 33: 2894-2898.

16. National Committee for Clinical Laboratory Standards. Performance standards for antimicrobial disc susceptibility tests. M2A2. Villanora, Pennsylvania, United States: NCCLS; 1992.

17. St Louis ME, Morse DL, Potter ME, DeMelfi TM, Guzewich JJ, Tauxe RV, et al. The emergence of grade $\mathrm{A}$ eggs as a major source of Salmonella enteritidis infections. New implications for the control of salmonellosis. JAMA 1988;259:2103-2107.

18. Vatopoulos AC, Mainas E, Balis E, Threlfall EJ, Kanelopoulou M, Kalapothaki V, et al. Molecular epidemiology of ampicillin-resistant clinical isolates of Salmonella enteritidis. J Clin Microbiol 1994;32:1322-1325.
19. Murase T, Okitsu T, Suzuki R, Morozumi $H_{,}$ Matsushima A, Nakamura A, et al. Evaluation of DNA fingerprinting by PFGE as an epidemiologic tool for Salmonella infections. Microbiol Immunol 1995;39:673-676.

20. Coyle EF, Palmer SR, Ribeiro CD, Jones HI, Howard AJ, Ward L, et al. Salmonella enteritidis phage type 4 infection: association with hen's eggs. Lancet 1988;2(8623):1295-1297.

21. Nair US, Saeed AM, Muriana PM, Kreisle RA, Barrett B, Sinclair CL, et al. Plasmid profiles and resistance to antimicrobial agents among Salmonella enteritidis isolates from human beings and poultry in the midwestern United States. J Am Vet Med Assoc 1995;206(9): 1339-1344.

22. Heffernan HM. Antibiotic resistance among Salmonella from human and other sources in New Zealand. Epidemiol Infect 1991;106: 17-23.

23. O'Brien TF, Hopkins JD, Gilleece ES, Medeiros AA, Kent RL, Blackburn BO, et al. Molecular epidemiology of antimicrobial resistance in Salmonella from animal and human beings in the United States. New Engl J Med 1982; 307:1-6.

24. Frost JA, Ward LR, Rowe B. Acquisition of a drug resistance plasmid which converts Salmonella enteritidis phage type 4 to phage type 24. Epidemiol Infect 1989;103:243-248.

Manuscript received 6 July 1999. Revised version accepted for publication on 8 June 2000.
RESUMEN

Análisis molecular de Salmonella enteritidis aisladas en el Caribe mediante electroforesis en gel con pulsos eléctricos
Mediante electroforesis en gel con pulsos eléctricos (EGPE), se analizaron las Salmonella enteritidis aisladas entre 1987 y 1996 en casos de gastroenteritis de cuatro países caribeños: Barbados, Saint Kitts y Nevis, Santa Lucía y Trinidad y Tabago. También se determinó la resistencia de los aislados a 12 antibióticos. La digestión del ADN con la endonucleasa de restricción $\mathrm{XbaI}$ reveló 13 patrones distintos de EGPE entre los 129 aislados de $S$. enteritidis analizados; los más prevalentes fueron el grupo 1 (88 de 129; $68,2 \%$ ) y el grupo 2 (26 de 129; 20,2\%). Estos patrones se correlacionaron con el origen geográfico de los aislados. Así, de los 28 aislados de Barbados, 20 (71,4\%) pertenecían al grupo 2, y de los 93 aislados de Trinidad y Tabago, 78 (83,9\%) pertenecían al grupo 1. La digestión del genoma de $S$. enteritidis con la endonucleasa de restricción SpeI no fue tan discriminativa como la digestión con XbaI. En general, 67 de los 129 aislados $(51,9 \%)$ mostraron resistencia a uno o más de los 12 antibióticos probados. La prevalencia de resistencia fue de $51 \%$ en los aislados de Trinidad y Tabago, de $50 \%$ en los de Barbados, de $28,6 \%$ en los de Santa Lucía y de 100\% en el único aislado de la isla de Saint Kitts. La mayor resistencia correspondió a la triple sulfamida (sulfamerazina, sulfadiazina y sulfametazina: 59 de $129 ; 45,7 \%$ ), seguida de la nitrofurantoína (10 de $129 ; 7,8 \%$ ), la ampicilina (7 de $129 ; 5,4 \%$ ) y la carbamicina (5 de $129 ; 3,9 \%$ ). 